\title{
The meaning of youth life in traffic violation prevention
}

\author{
Maya Mashita Rachmi ${ }^{1}$, Firman Firman ${ }^{1}$ \\ ${ }^{1}$ Universitas Negeri Padang, Indonesia
}

\begin{tabular}{l}
\hline Article Info \\
\hline Article history: \\
Received Sep $15^{\text {th }}, 2020$ \\
Revised Oct $17^{\text {th }}, 2020$ \\
Accepted Nov $06^{\text {th }}, 2020$ \\
\hline
\end{tabular}

\section{Keyword:}

The meaning of life

Traffic violations

\begin{abstract}
The high rate of traffic violations and accidents among adolescents is a real problem, especially when no effective solution has been found to reduce these violations. In fact, from year to year, cases of traffic violations among teenagers are increasing. The purpose of this study is to measure the meaning of adolescent life in traffic violation prevention. This type of research is a descriptive study with a quantitative approach, using a data collection tool in the form of a meaningful life questionnaire with a validity greater than 0.361 and a reliability of 0.964 . The subjects of this study were vocational high school students. Subjects were taken using simple random sampling technique. This study uses data analysis techniques with descriptive analysis. The results of this study indicate that the meaning of student life consists of various aspects. Each aspect has a different percentage. The aspect of freedom of will has the lowest percentage of $10 \%$, the aspect of decency of life has a percentage of $12 \%$, the aspect of attitude towards death has a percentage of $23 \%$ and the aspect of purpose / meaning of life has the highest percentage of $42 \%$. The results of this study can be used as information for counseling teachers or counselors as a basis for efforts to provide assistance to students to increase the meaning of life in order to prevent negative behavior, one of which is traffic violations that often occur in adolescents.
\end{abstract}

(C) 2020The Authors. Published by Redwhitepress.

This is an open access article under the CC BY-NC-SA license (https://creativecommons.org/licenses/by-nc-sa/4.0/

\section{Corresponding Author:}

Maya Mashita Rachmi,

Universitas Negeri Padang

Email: mayarahmi94@gmail.com

\section{Introduction}

Adolescence is the age when individuals integrate into adult society, the age where they feel they are on the same level as older people at least in terms of rights, including intellectual changes and transformations that are typical of the way of thinking of adolescents that make it possible to achieve integration. This is because adolescents begin to actively achieve activities to determine themselves and life guidelines for their future (Hurlock, 1980). Adolescence is a period in which individuals leave childhood towards adulthood (Sari et al., 2018). Traffic violation is a condition where there is a mismatch between the rules and the implementation, the rules in this case are the laws that have been established and agreed upon by the state as laws that apply legally, while the implementation is humans or the people of a country who are bound by the law (Sadono, 2015). This is stated in Law of the Republic of Indonesia Number 22 of 2009, which contains road traffic and transportation (Melasari, 2017).

Several forms of traffic violations committed by teenagers include: 1) driving in a way that endangers traffic order or safety (Rakhman, 2016), 2) driving a motorized vehicle that cannot show administration (Rakhmani, 2013) ,3) allowing motorized vehicles are driven by other people who do not have a driver's license (SIM) (Muryatma, 2017), 4) driving a vehicle that exceeds the specified speed limit (Krisnawati, Elly 
Kismini, 2016), through traffic (Umi Enggarsasi, 2017), zigzag driving at high speed (Djaja et al., 2016), does not complete safety equipment such as not using a helmet, mirrors (Fatmaningsih et al., 2018) ,and vehicle lights (Sadono, 2015).

The result of traffic violations is traffic accidents that are very dangerous to oneself and others (Surya, 2017). This is proven by the fact that traffic accidents are the "number three killer" in the world after heart disease and tuberculosis (Agung, 2014). WHO data for 2016 recorded that 1.2 million people die each year in traffic accidents and 50 million are the main cause of death among young people aged 15 to 29 years (Handayani et al., 2017). Deery and Flides (1999) stated that teenagers have the potential to become risk drivers. Adolescents tend to adopt a more risky way of driving than parents (Agung, 2014).

The West Sumatra Regional Police quoted from Republika also noted that there was an increase in the number of traffic accidents and traffic violations throughout 2018. The West Sumatra Police Chief said that the number of traffic accidents in 2018 was 2,912 cases, up 17\% compared to 2017 of 2,862 cases. Meanwhile, the number of traffic violations increased by $22.23 \%$, namely in 2018 as many as 123,256 cases, greater than in 2017 of 101,003 cases (Republika 2019). According to Konopka in (Wardani, 2012), data on traffic violations in West Sumatra Province, especially Padang City, is also dominated by students. which are seen as having new values, which is a process to determine the meaning of life. It is unfortunate that an effective solution cannot be found immediately because teenagers as the millennial generation should have better education and are accustomed to technology, are confident, work creatively and have the spirit to achieve a goal (Firman, 2018).

According to data from the Indonesian police, it is stated that the large number of traffic accidents is caused by human factors (Kemkes Republik Indonesia, 2019). The high level of human factors from these data illustrates the lack of meaningfulness in life for adolescents. Erikson (Papalia, D. E., \& Feldman, 2012) stated that in their adolescence, they were looking for a form of self-identity and meaning in their lives. The meaning of life itself can be manifested in a desire to be a useful person for others, whether it be children, spouses, close family, community, state and mankind (Anggriany, 2006). The importance of meaningful life for students will be able to direct their behavior to a better direction. However, the loss of the meaning of life will make adolescents have no clear direction and purpose in life, they don't know what to do (Mazaya \& Supradewi, 2011), lose interest, get bored, feel their life is meaningless and apathetic (Ghozali, 2019). When the meaning of life is successfully fulfilled, a person will experience a meaningful life and ultimately achieve a feeling of happiness. This problem must be addressed as soon as possible so as not to hinder students in social processes at school and in the community. However, what happens in the field is that the implementation of counseling only discusses overcoming learning, social, personal and career problems (Firman et al., 2018), few of the counselors discussed the importance of life meaning, especially in terms of preventing traffic violations in students.

Based on the phenomena and explanations mentioned, it can be concluded that when adolescents can understand and find the meaning of life in themselves, in the future life will be lived more carefully, including in terms of traffic.

\section{Method}

This research is a descriptive research with a quantitative approach. This study aims to determine the level of life meaningfulness of vocational school students in Padang City. With the research population of vocational students in the city of Padang, amounting to 28 State Vocational Schools and 12 Private Vocational Schools. The research sample was taken by means of simple random sampling totaling 100 students from 4 different schools. The data collection technique in this study used a non-test with an instrument of meaningful life in traffic with five categories of answers, namely strongly agree, agree, doubt, disagree, and disagree according to student conditions in the field. Data analysis was performed using descriptive analysis.

\section{Results and Discussions}

The meaning of life that is meant in research is how students can understand themselves and the meaning of life and have a purpose in life so that student activities are directed to the development of positive personal potentials, so that later they can prevent a high level of traffic violations and not fall into the influence of the environment and wrong association. In line with the opinion (Anggriany, 2006) that the meaning of life for adolescents is a teenager's appreciation of the quality, goals and hopes in life so that they can be meaningful to themselves and others, as well as the fundamental thing about the meaning of life, namely the desire or commitment to be meaningful to oneself. and the environment. 
The aspects used in this study use five of the six aspects of the meaning of life according to Crumbaugh \& Maholich, namely the purpose / meaning of life, life satisfaction, freedom of will, attitudes towards death and life worthiness (Koeswara, 1992). Adolescents have a low life meaning because they do dangerous things such as driving at high speeds (Handayani et al., 2017).This is in accordance with the results of a survey conducted by Gatran (Amalia et al., 2017) of 800 adolescent respondents aged 15-22 years in Jakarta, Yogyakarta, Medan, Surabaya and Makassar, it was found that Indonesian adolescents tend to be apolitical and apathetic towards the situation, which is an example of the meaningless life syndrome in adolescents.

The purpose/meaning of life is everything that is made the purpose of life so that if it is found and fulfilled it will cause life to be felt so meaningful and valuable, this means that the meaning of life can be positively associated with psychological well-being in adolescents (Viqri Novielza Putri, Ifdil, Yusri, 2017). The same thing was stated by (Dezutter et al., 2013) based on the results of research which showed that individuals who are characterized by a high level of meaning in life will be characterized by a greater level of welfare. Life satisfaction is a person's assessment of the life he lives, to what extent he is able to enjoy and feel satisfaction in life and all the activities he has done (Cahyani, 2011). Freedom of will is the ability of a person to control the freedom of life responsibly so that they can be careful in their actions (Bukhori, 2012), this is in line with Frankl's opinion (Anggawati, 2008) which states that the characteristics of adolescents who are able to absorb the meaning of life include freedom to choose steps or actions. alone and personally responsible for attitudes and behavior. Attitude towards death is how a person views and is prepared to face death that every human being will surely face. Appropriateness of life is a view of something that is experienced whether it is appropriate or not, a person's assessment of his life, the extent to which the individual feels that what he has experienced in life is something that is normal as well as a benchmark for him about why life needs to be fought for. Individuals who live the meaning of their lives are always passionate and optimistic, flexible but do not get carried away or lose their identity (Wardani, 2012).

The results of the data analysis of the meaning of life in student traffic are generally categorized into three categories, namely low, medium and high as shown in the following table.

Table 1. Distribution of the Meaningful Life Frequency of Padang City Vocational School Students

\begin{tabular}{|c|c|c|}
\hline Interval & Kategori & $\bar{F}$ \\
\hline $115-150$ & High & 15 \\
\hline $79-114$ & Moderate & 62 \\
\hline $43-78$ & Low & 23 \\
\hline \multicolumn{2}{|c|}{ TOTAL } & 100 \\
\hline
\end{tabular}

In table 1 it is known that of the total 100 students, there are 15 students who have meaningful life in traffic in the high category, and 62 students are in the medium category, and 23 students are in the low category. This is also consistent with the results of a survey in San Francisco regarding the level of meaning in life by Diana Young, that adolescents occupy the lowest position. Another study conducted by Augustine Meier also stated that the lowest level of meaning was occupied by adolescents aged 17-19 years, followed by adolescents aged 13-15 years (Nafisah, n.d.). The data on the meaning of life in the traffic that has been collected are then analyzed using percentages. Based on the results of data analysis, a detailed description of the meaning of life in the traffic of vocational students in Padang City is as follows.

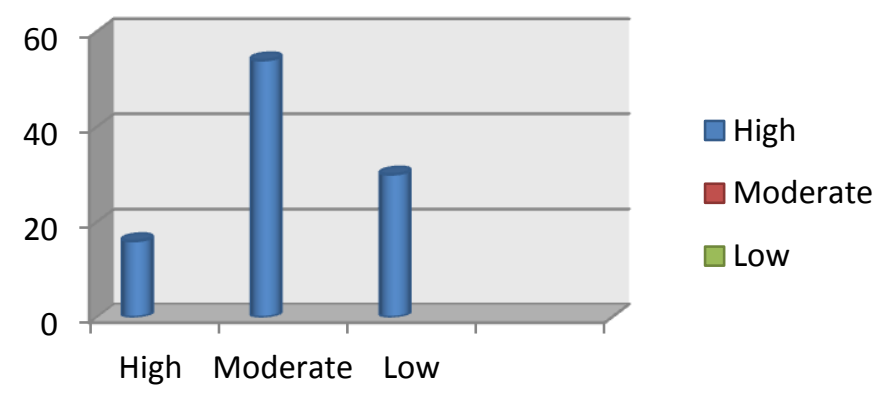

Figure 1. Percentage of Life Meaning in Traffic of Padang City Vocational School Students 
Based on the results of the percentage of life meaning in the traffic of students at SMK Kota Padang, it can be seen that there are students who have a high category percentage of $16 \%$. Ideally, this high category should be developed in students. According to Reker \& Peacock that systematic efforts in identifying the meaning of life include goals, acceptance of death, achieving goals, the perception that the future will be meaningful, existential emptiness, controlling feelings in life, and the desire for meaning in life (Martela, F., \& Steger, 2016). But in reality, the results of the analysis of the data obtained show that there are still $54 \%$ students who have a meaningful life in moderate traffic and as many as $30 \%$ low. To be clearer, the following describes the meaning of life in student traffic in each of the aspects which can be seen in table 2 below.

Table 2. Descriptive Aspects of Life Meaningfulness of Students in Padang City Vocational School

\begin{tabular}{|c|c|c|c|c|c|c|c|c|c|c|}
\hline \multirow[t]{2}{*}{ Category } & \multicolumn{2}{|c|}{$\begin{array}{c}\text { Purpose / } \\
\text { Meaning of } \\
\text { Life }\end{array}$} & \multicolumn{2}{|c|}{ Life Satisfaction } & \multicolumn{2}{|c|}{ Freedom of Will } & \multicolumn{2}{|c|}{$\begin{array}{c}\text { Attitude } \\
\text { Toward Death }\end{array}$} & \multicolumn{2}{|c|}{$\begin{array}{c}\text { Appropriateness } \\
\text { of Life }\end{array}$} \\
\hline & $\mathbf{F}$ & $\%$ & $\mathbf{F}$ & $\%$ & $\mathbf{F}$ & $\%$ & $\mathbf{F}$ & $\%$ & $\mathbf{F}$ & $\%$ \\
\hline High & 35 & $35 \%$ & 19 & $19 \%$ & 10 & $10 \%$ & 37 & $37 \%$ & 12 & $12 \%$ \\
\hline Moderate & 40 & $40 \%$ & 65 & $65 \%$ & 78 & $78 \%$ & 45 & $45 \%$ & 80 & $80 \%$ \\
\hline Low & 25 & $25 \%$ & 16 & $16 \%$ & 12 & $12 \%$ & 18 & $18 \%$ & 8 & $8 \%$ \\
\hline score & 100 & $100 \%$ & 100 & $100 \%$ & 100 & $100 \%$ & 100 & $100 \%$ & 100 & $100 \%$ \\
\hline
\end{tabular}

Table 2 describes the meaning of life in traffic for students of vocational high School Padang City with the percentage score on each aspect of the meaning of life. First, the purpose / meaning of life has the highest percentage in the medium category. Second, life satisfaction has the highest percentage in the medium category. Third, freedom of will has the highest percentage in the medium category. Fourth, the attitude towards death has the highest percentage in the high category. Fifth and life appropriateness has the highest percentage in the medium category. Based on the data above, it can be interpreted that the meaning of life in the traffic of vocational school students in the city of Padang is partly in the high category, especially in the aspect of the purpose / meaning of life. Students who have meaning in life will try to make themselves into good individuals for their future, behave and behave well (Viqri Novielza Putri, Ifdil, Yusri, 2017). However, of the five aspects studied, the aspects of freedom of will and properness of life have the lowest percentage, this situation can be seen at the time of passing the final exam where many students express their relief with graffiti on uniforms and tracks or convoys (Susanto et al., 2012) or driving in a way that endangers traffic order or safety (Rakhman, 2016). This can mean that vocational students still need to get more attention in improving aspects of freedom of will and properness of life so that with the increasing aspects of freedom of will and properness of life, the meaning of life in traffic for vocational students will also increase.

Further descriptions regarding the percentage of life meaning in traffic in each aspect in more detail are presented in the following figure.

\title{
Meaningful Aspects of Life Traffic of Padang City...
}

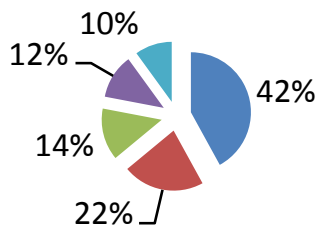

\author{
Purpose / Meaning \\ of Life \\ Life Satisfaction
}

Figure 2. Meaningful Aspects of Life Traffic of Padang City Vocational School students

The analysis of the results of the meaningfulness of life in the traffic of students vocational high School Padang City shows that the meaning of student life consists of various aspects. Each aspect has a different percentage. The aspect of freedom of will has the lowest percentage of $10 \%$, the aspect of life appropriateness is $12 \%$, then the aspect of attitude towards death has a percentage of $15 \%$, the aspect of life satisfaction has a 
percentage of $23 \%$ and the aspect of purpose / meaning of life has the highest percentage of $43 \%$. Individual success in developing a meaningful life is done by realizing and actualizing human potentials and qualities through various activities aimed at fulfilling the meaning of life (Aziz, 2018).

The things that guidance and counseling teachers can do in the future are very important in helping adolescents in the stage of increasing the meaning of their lives, with various services provided at school, such as (1) information services, (Restu \& Yusri, 2013) by trying to meet student shortages of information about meaning. / life goals, life satisfaction, freedom of will, attitudes towards death, and life suitability for the benefit of life and future development of adolescents, (2) individual counseling services, (Bastaman, 2007) guidance and counseling teachers can provide psychological assistance to adolescents to fulfill the meaning / purpose of life or various other aspects by being more aware of the sources of the meaning of life, actualizing one's potential, increasing the intimacy of interpersonal relationships, thinking and acting positively, (3) content mastery services, (Marfita et al., 2013) teacher guidance and counseling seeks to develop youth morale by applying various aspects of $\mathrm{k}$ meaning of life.

\section{Conclusions}

This research is a research with the subject vocational high School Padang City. The results showed that some students Vocational High School Padang City have a tendency to have a meaningful life in traffic in the medium and even low category. Some forms of meaningful life in low traffic are in the aspects of freedom of will, worthiness for life, attitude towards death. Besides that, the meaning of life in high traffic is also in the aspects of the purpose / meaning of life and the appropriateness of life. The results of this study can be used as information for the counselor or counselor as a basis in an effort to provide assistance to students to increase the meaning of life in order to prevent frequent traffic violations on the highway for students. And also as an effort to help develop abilities in students.

\section{References}

Agung, I. M. (2014). Model perilaku pengendara berisiko pada remaja. Jurnal Psikologi Integratif, 2(2), 35-41.

Amalia, M., Hidayah, N., \& Fauzan, L. (2017). Meaning of life siswa sekolah menengah pertama dengan latar belakang budaya samin. Jurnal Kajian Bimbingan Dan Konseling, 2(3), 97-106. https://doi.org/10.17977/um001v2i32017p097

Anggriany, N. (2006). Motif sosial dan kebermaknaan hidup remaja Pagaralam. Psikologika: Jurnal Pemikiran Dan Penelitian Psikologi, 11(21). https://doi.org/10.20885/psikologika.vol11.iss21.art5

Aziz, R. (2018). Pengaruh Kreatifitas dalam bekerja terhadap kebermaknaan hidup. Jurnal Psikologi Pendidikan \& Konseling, 4(2), 151-157.

Bastaman, H. D. (2007). Psikologi untuk Menemukan Makna Hidup dan Meraih Hidup Bermakna. PT Raja Grafindo Persada.

Bukhori, B. (2012). Hubungan kebermaknaan hidup dan dukungan sosial keluarga dengan kesehatan mental narapidana (Studi kasus nara pidana Kota Semarang). Ad-Din, 4(1), 1-19.

Cahyani, S. T. (2011). The meaning of life people's with diabetes mellitus in adult associate. Gunadarma University.

Dezutter, J., Casalin, S., Wachholtz, A., Luyckx, K., Hekking, J., \& Vandewiele, W. (2013). Meaning in Life: An Important Factor for The Psychological Well-Being of Chronically Ill Patients. Rehabilitation Psychology, 58, 334-341.

Djaja, S., Widyastuti, R., Tobing, K., Lasut, D., \& Irianto, J. (2016). Description of traffic accident in indonesia, year 2010-2014. Jurnal Ekologi Kesehatan, 15(1), 30-42.

Fatmaningsih, Z., Sugiharto, D. Y. P., \& Hartanti, M. T. S. (2018). Meningkatkan sikap disiplin berlalu lintas melalui layanan bimbingan kelompok dengan teknik role playing. Indonesian Journal of Guidance and Counseling: Theory and Application, 7(1).

Firman. (2018). Pendekatan konseling sebaya tepat guna untuk generasi milenial dalam perubahan sosial budaya. 1.

Firman, Karneli, Y., \& Harikoa, R. (2018). Improving students' moral logical thinking and preventing violent acts through group counseling in senior high schools. Advance Science Letters, 1(24), 24-26.

Ghozali, M. (2019). Hubungan konsep diri dan self sontrol dengan kebermaknaan hidup. Indonesian Psychological Research, 01(01), 11-24.

Handayani, D., Ophelia, R. O., Hartono, W., \& Maret, U. S. (2017). Pengaruh pelanggaran lalu lintas terhadap potensi kecelakaan pada remaja pengendara sepeda motor. E-Jurnal Matriks Teknik Sipil, 838843.

Hurlock, E. (1980). Psikologi Perkembangan: Suatu Pendekatan Sepanjang Kehidupan (Istiwidiyanti \& Soedarjo, Eds.). Erlangga. 
Kemkes Republik Indonesia. (2019). Rata-rata tiga orang meninggal setiap jam akibat kecelakaan jala.

Krisnawati, Elly Kismini, A. S. S. (2016). Makna perilaku siswa dalam perayaan kelulusan ujian pada SMK negeri 1 Rembang tahun ajaran 2014/2015. Jurnal Solidarty, 5(2).

Marfita, Y., Zikra, \& Yusri. (2013). Pendapat siswa tentang upaya guru bimbingan dan konseling dalam pengembangkan moral siswa. Jurnal Konselor, 2(4).

Martela, F., \& Steger, M. F. (2016). The Three Meanings of Meaning in Life: Distinguishing Coherence, Purpose, and Significance. Journal of Positive Psychology, 11(5), 531-545.

Mazaya, K., \& Supradewi, R. (2011). Konsep diri dan kebermaknaan hidup pada remaja di panti asuhan. Jurnal Proyeksi, 6(2), 103-112.

Melasari, J. (2017). Jenis pelanggaran dan manuver lalu lintas yang membahayakan keselamatan pada persimpangan Kota Padang ( Studi Kasus: Simpang Empat Bersinyal M . Hatta Bypass ). Jurnal Teknologi, 7(1), 101-110.

Muryatma, N. M. (2017). Hubungan antara faktor keselamatan berkendara dengan perilaku keselamatan berkendara. Jurnal Promkes, 5(2), 155-166.

Nafisah, S. J. (n.d.). Arti kebermaknaan anak panti asuhan. Jurnal Penelitian Pendidikan, 33-41.

Papalia, D. E., \& Feldman, R. D. (2012). Human Development (A. K. Anwar, Ed.). Kencana.

Rakhman, M. Y. N. (2016). Reproduksi Pelanggaran Peraturan Lalu Lintas yang Dilakukakan oleh Pelajar Sekolah Menengah Atas di Kota Surakarta.

Rakhmani, F. (2013). Kepatuhan remaja dalam berlalu lintas. Jurnal Sociodev, 2(1), 1-7.

Restu, Y., \& Yusri. (2013). Studi tentang perilaku agresif siswa di sekolah. JJurnal Konselor, 2(1).

Sadono, S. (2015). Budaya tertib berlalu lintas kajian fenomenologis atas masyarakat pengendara sepeda motor di kota bandung. 151(september 2016), 10-17. https://doi.org/10.1145/3132847.3132886

Sari, A. P., Ilyas, A., \& Ifdil. (2018). Tingkat kecanduan internet pada remaja awal. Jurnal Penelitian Pendidikan Indonesia, 3(110-117).

Surya, D. H. (2017). Tinjauan kriminologi terhadap prilaku menyimpang di kalangan remaja ( studi kasus pelanggaran kelengkapan Berkenderaan di Sekolah menengah kejuruan negeri pertanian terpadu Provinsi Riau ). Jurnal Askara Public, 1(1), 30-46.

Susanto, L., Dutto, D., \& Sylvia, M. (2012). Perancangan kampanye sosial modifikasi baju seragam SMA saat kelulusan. 1-12.

Umi Enggarsasi, N. K. S. (2017). Kajian terhadap faktor-faktor penyebab kecelakaan lalu lintas dalam upaya perbaikan pencegahan kecelakaan lalu lintas. Jurnal Perspektif, 22(3), 228-237.

Viqri Novielza Putri, Ifdil, Yusri, F. M. Y. (2017). Profil kebermaknaan hidup siswa membolos pendahuluan. JAIPTEKIN | Jurnal Aplikasi IPTEK Indonesia, 4(2), 126-135.

Wardani, I. R. K. (2012). Hubungan cita rasa humor (sense of humor) dengan kebermaknaan hidup pada remaja akhir (mahasiswa). Jurnal Sosiohumaniora, 3(3), 78-88. 